\title{
SYMPOSIUM ON INVESTOR RESPONSIBILITY: THE NEXT FRONTIER IN INTERNATIONAL INVESTMENT LAW
}

\section{INVESTOR RESPONSIBILITIES FROM A HOST STATE PERSPECTIVE: QUALITATIVE DATA AND PROPOSALS FOR TREATY REFORM}

\section{Mavluda Sattorova*}

The need to address negative impacts of foreign investment on the environment, public health, and human rights has long been acknowledged. ${ }^{1}$ Drawing on recent case studies, this essay focuses on a number of concerns that arise when investors seek to unduly influence host government decision-making, including in the context of national policy-making in the public interest. ${ }^{2}$ This essay argues that International Investment Agreements (IIAs) should begin to more directly incorporate investor responsibilities so to avoid detrimental societal impacts of foreign investment and to maximize foreign investment's positive contribution to host communities. ${ }^{3} \mathrm{~A}$ fundamental reframing of IIA objectives is key in overcoming the existing resistance to incorporating investor obligations in new and amended treaties.

\section{Investor Leverage Over Host States: Examples from Case Studies}

While empirical analyses of the impact of international investments on host states still remain limited, ${ }^{4}$ there is an emerging body of empirically-oriented scholarship that interrogates various aspects of the interaction between IIAs and host governments. ${ }^{5}$ Although the primary focus of these studies has been on the interplay between IIAs and national decision-making, they shed light on issues concerning investor responsibilities. For instance, recent qualitative case-studies in eight developing states reveal widespread concerns about the effects of investor conduct in host states. ${ }^{6}$ The case studies comprised interviews with government officials who work or have worked in the ministries and agencies involved, directly or indirectly, in the process of making, implementing, or otherwise applying investment-related international and national laws. The respondents were drawn from a variety of agencies and

* University of Liverpool, School of Law.

${ }^{1}$ UNCTAD, World InVestment Report 2015: Reforming International InVEStMent Governance 126.

${ }^{2}$ See, e.g., Kyla Tienhaara, Regulatory Chill and the Threat of Arbitration: A View From Political Science, in Evolution IN INVESTMENT Treaty Law and Arbitration 606 (Chester Brown \& Kate Miles eds., 2011); Christine Côté, A Chilling Effect? The impact of International Investment Agreements on National Regulatory Autonomy in the Areas of Health, Safety and the Environment (PhD Thesis, LSE, 2014).

${ }^{3}$ UNCTAD, supra note 1 , at 126.

${ }^{4}$ See, e.g., Lauge N. Skovgaard Poulsen, Bounded Rationality and Economic Diplomacy: The Politics of Investment Treaties in Developing Countries (2015).

5 See Tienhaara, supra note 2, and Côté, supra note 2.

${ }^{6}$ Some case studies are discussed in Mavluda Sattorova, The Impact of Investment Treaty Lai on Host States: Enabling Good GOVERNANCE? 61-70 (2018).

\footnotetext{
The American Society of International Law and Mavluda Sattorova (C) 2019. This is an Open Access article, distributed under the terms of the Creative Commons Attribution licence (http://creativecommons.org/licenses/by/4.0/), which permits unrestricted reuse, distribution, and reproduction in any medium, provided the original work is properly cited.
} 
ministries responsible for investment promotion and development, municipal administration, prosecution and internal affairs, anticorruption, public health, and innovation, as well as the legislature and the judiciary.

One common theme that emerges from the case studies is a shared concern about the effects of investor behavior on government decision-making. ${ }^{7}$ A cross-section of the government officials interviewed recounted the efforts by foreign corporations to influence the desirability and content of public health, planning, and environmental regulations. For example, in one case study, respondents from five countries recalled instances when, driven by the fear of displeasing the prospective investor and losing investment, senior government officials chose not to insist on the inclusion of public policy-friendly provisions in an investment agreement. ${ }^{8}$ In one developing country, collusion between foreign corporations and government officials in the pharmaceuticals sector was so common that a number of respondents referred to those two sets of actors as the "pharma mafia." The respondents from another developing country described a well-documented incident in which a multinational tobacco company attempted to thwart the adoption of a new policy on tobacco control. ${ }^{10}$ These responses resonate with the conclusions of a different recent empirical study about IIAs and regulatory chill, ${ }^{11}$ which found that industry influence was one of the key factors in shaping public policy-making in developing countries. The emerging data confounds the traditional portrayal of foreign investors as "victims of opportunistic politicians." 12 International investors exercise considerable political influence over governmental decision-making, and can often be authors as well as benefactors of domestic regulations.

The interviews also highlight a widespread awareness of the involvement of foreign investors in corruption and bribery. As one respondent observed, "Foreign investors need stability and predictability. They had that with the informal rule established by [the previous president]. They would pay, say, $10 \%$ and everything would be sorted." 13 A similar picture emerges from a case-study in another developing state, where corrupt dealings between international oil companies and the ruling elite triggered violent protests in local communities. Investor complicity in bribery and other forms of corruption are also well-documented in a number of investment arbitration awards. ${ }^{14}$ The qualitative data suggest that foreign investors frequently contribute to poor governance by normalizing corruption, bribery, and regulatory capture in host states. As Hirsch observed, "П]nternational investments are not only affected by socio-cultural factors, they often influence the socio-cultural features of the involved communities." 15

\footnotetext{
7 See Tienhaara, supra note 2, and Côté, supra note 2.

${ }^{8}$ As one interviewee put it, "[F] oreign investors are ... known for their lobbying and otherwise influencing the government to get the outcome they want, for instance a hands-off regulation of a relevant industry." SATTOROVA, supra note 6, at 149.

${ }^{9}$ Id. at 149 .

${ }^{10} \mathrm{Id}$. Having learned about the government's plans to introduce health warnings and smoking-free zones, the company condemned the proposed regulations as "seriously interfering with ... commercial freedom" and threatened to withdraw its investment. See Anna B. Gilmore et al., British American Tobacco's Erosion of Health Legislation in Uzbekistan, 332 BMJ 355 (2006); Jennifer Knight \& Simon Chapman, Asia is Now the Priority Target for the World Anti-Tobacco Movement: Attempts by the Tobacco Industry to Undermine the Asian Antismoking Movement, 13 ToBacco Control 1130-36 (2004).

11 See Côté, supra note 2.

12 M. Sornarajah, The International Law on Foreign Investment 78 (2004).

${ }^{13}$ SATtorova, supra note 6, at 149.

14 See, e.g., World Duty Free v. Kenya, ICSID Case No. ARB/00/7, Award (Oct. 4, 2006); Wena Hotels v. Egypt, ICSID Case No. ARB/ 98/4, Award (Dec. 8, 2000); and Azpetrol v. Azer., ICSID Case No. ARB/06/15, Award (Sept. 8, 2009).

${ }^{15}$ Moshe Hirsch, The Sociology of International Investment Law, in The Foundations of International Investment Law: Bringing Theory Into Practice 146 (Zachary Douglas et al. eds., 2014).
} 


\section{Investor Misconduct and the Limitations of Interpretive Solutions}

The asymmetry of the investment treaty regime-its traditional preoccupation with guaranteeing investor rights but not responsibilities - has long been criticized. These criticisms have been dismissed by some authors as conceptually "rather simplistic and not always accurate," 16 particularly in light of the fact that national laws of host states and investor-state contracts can impose obligations on investors. Instead of incorporating enforceable investor obligations into treaty texts, some authors call for "a change of mindset" whereby IIAs should be seen as part of a wider array of sources and construed in a more balanced manner. ${ }^{17} \mathrm{~A}$ similar preference for interpretive rather than treaty-based reform solutions can be discerned in proposals to harness the notion of contributory fault when calculating damages in cases involving investor complicity in illegal acts. ${ }^{18}$ Although these solutions could indeed prove useful in addressing the consequences of investor misconduct in some cases, their overall long-term effectiveness is likely to be limited due to the lack of binding precedent and the difficulties that arise because of the inconsistency of arbitral jurisprudence.

While some arbitral tribunals have looked to domestic laws and treaty preambles to fill the void created by investment treaties' silence on investor obligations, other tribunals have refused to take into account the illegality of the investor's behavior in deciding the latter's eligibility for investment treaty protection. ${ }^{19}$ For instance, when faced with evidence of investor misconduct, the arbitral panel in Fakes $v$. Turkey dismissed the relevance of the principles of good faith and legality in its interpretation of the definition of "investment." In the tribunal's view, whether "an investment might be 'legal' or 'illegal,' or made in good faith or not, it nonetheless remains an investment." 20 The usefulness of jurisprudential solutions may also be limited for resource-poor developing states, which lack sufficient economic and legal capacity to successfully defend themselves in investor-state arbitration cases. In comparison to cash-strapped developing country governments, multinational corporations are likely to be more influential in shaping the content and direction of international investment jurisprudence. ${ }^{21}$ These factors make a strong case for amending IIAs.

\section{The Need for Substantive (and Enforceable) Investor Obligations in New Investment Treaties}

It is striking, however, that at a time when many of the long-criticized aspects of the IIA regime are being addressed through reform, the newly emerging treaty models still largely fail to take a strong and effective stance on investor responsibilities. Several solutions to this problem present themselves. First, while the bulk of existing IIAs contain no express provisions on investor responsibilities, a growing number of treaties recognize the relevance of investor conduct. This category of IIAs seeks to address issues arising from investors' (mis)conduct primarily by (1) stipulating host state obligations to fight bribery and corruption and (2) safeguarding host state rights to protect the environment, human rights, and labor standards. For instance, the CARIFORUM-EU Economic Partnership Agreement ${ }^{22}$ requires the contracting states parties to cooperate and take any necessary domestic

\footnotetext{
${ }^{16}$ Jorge E. Viñuales, Investor Diligence in Investment Arbitration: Sources and Arguments, 32 ICSID Rev. 346, 367 (2017).

17 Id. at 367 .

18 Yarik Kryvoi, Economic Crimes in International Investment Law, 67 Int'l \& Comp. L.Q. 577 (2018). See also Bear Creek Mining v. Peru, ICSID Case No. ARB/14/21, Award paras. 4, 35-40 (Sands, dissenting) (Nov. 30, 2017).

${ }^{19}$ Sattorova, supra note 6, at 155-56.

${ }^{20}$ Saba Fakes v. Turkey, ICSID Case No ARB/07/20, Award, para. 112 (July 12, 2010).

21 Julian Arato, Corporations as Lawmakers, 56 Harv. InT'L L.J. 301 (2015).

22 Economic Partnership Agreement Between the CARIFORUM States and the European Community art. 72, Oct. 30, 2008 , 2008 O.J. (L 289) I/3.
} 
measures to ensure that investors are forbidden from and held liable for bribing public officials. Yet the onus is on contracting states, not investors. Due to their declaratory language and focus on the states parties as principal bearers of the relevant responsibilities, such provisions are likely to prove ineffective in preempting investor misconduct.

The second category of drafting solutions emerging from the ongoing investment treaty reform is exemplified by Article 8.18.3 of the Comprehensive Economic and Trade Agreement between the European Union and Canada (CETA), which forecloses an investor's access to investor-state dispute settlement (ISDS) where its investment has been made through fraudulent misrepresentation, concealment, corruption, or conduct amounting to an abuse of process. This jurisdictional requirement is addressed to tribunals and seeks to deter investor misconduct by precluding those behind illegal investments from availing themselves of ISDS. Although it does not revolutionize the existing approaches to investor responsibilities, the CETA approach goes some way towards addressing the deep-seated structural imbalance within international investment law. Nevertheless, the significant shortcoming of this drafting solution is that its scope is limited to the initial period of making the investment. It does not impose a continuous obligation to act in good faith and refrain from unlawful conduct in operating the investment. Not all investment projects lead to ISDS, and even those that result in investment claims may be settled before reaching the jurisdictional stage.

In light of growing concerns about investor leverage over host governments, particular efforts should be made to incorporate investment treaty provisions that expressly address the exercise by investors of improper influence over government officials. Some of the new generation treaties merely acknowledge the importance of preempting such behavior. To prevent a negative impact of investment activities on national policy-making in the public interest, states should redesign IIAs to impose bolder obligations directly on investors, expressly prohibiting any form of direct or indirect influence over government officials. Such provisions should be enforceable through the treatybased dispute settlement mechanisms. While this would "considerably modify the normative structure of investment agreements," 23 there is growing consensus that such modifications are warranted in order to redress the existing lack of provisions on investor responsibilities. ${ }^{24}$ The International Institute for Sustainable Development model treaty contains a useful drafting template: it envisages an investor obligation not to offer, promise, or give any undue pecuniary or other advantage to a public official of the host state in order to achieve any favor in relation to a proposed investment. The model treaty also requires investors to refrain from incitement, aiding and abetting, and conspiracy to commit or authorization of such acts. ${ }^{25}$

Crucially, states can and should redesign investment treaties not only to avoid detrimental impacts of investment ("doing no harm") but also to maximize the positive contribution that investors can bring to societies ("doing good"). ${ }^{26}$ IIAs should go beyond a duty to comply with the host state laws by expressly stipulating an obligation to undertake activities consistent with international and national environmental, human rights, and labor standards. ${ }^{27}$ This would require revisiting all core substantive and procedural provisions-from the definition of investment to standards of treatment and dispute settlement. Treaty-makers can draw inspiration from the emerging innovative drafting solutions designed to encourage and increase sustainable investments with a view to meeting the climate change mitigation and adaptation goals. ${ }^{28}$

${ }^{23}$ Karsten Nowrot, How to Include Environmental Protection, Human Rights and Sustainability in International Investment Law, 1 J. WORLD INV. \& Trade 612, 638 (2014).

${ }^{24}$ For recent proposals, see Arbitrating The Conduct of International Investors (Jose D. Amado et al. eds., 2017).

${ }^{25}$ Int'l Inst. for Sustainable Dev., Model International Agreement on Investment for Sustainable Development (Apr., 2005).

${ }^{26}$ UNCTAD, supra note 1 , at 126.

27 See Int'l Inst. for Sustainable Dev., supra note 25, arts. 11 and 12.

${ }^{28}$ Martin Brauch, Tackling Climate Change Through Sustainable Investment: All in a Treaty?, IISD SDG HuB (2018). 


\section{Overcoming Systemic Barriers to Investment Treaty Innovation?}

States have not yet implemented proposals to comprehensively address investor responsibilities in an actual investment treaty. It is also noteworthy that, unlike the amended treaties of developed economies, some efforts to address investor responsibilities can be found in IIAs signed between developing states, such as the 2016 Slovakia-Iran IIA and Nigeria-Morocco IIA. ${ }^{29}$ The majority of existing treaties and reformed IIAs of major economic powers such as the United States, the European Union, Japan, and China continue to fall short of providing a meaningful mechanism to regulate the investor behavior. As one of the world's largest exporters and importers of foreign direct investment, the European Union exercises considerable leverage ${ }^{30}$ in the ongoing reform process but, regrettably, its most recent treaties and its negotiating objectives for new mega-regional agreements do not feature effective and comprehensively-framed investor obligations.

To overcome the reluctance to make investor obligations part and parcel of new IIAs, we need to address a lack of political will, skepticism towards treaty innovations, and possible resistance from the business community. ${ }^{31}$ Those who oppose the inclusion of investor obligations in treaties also argue that, unlike the host state, which incurs international legal responsibility for unlawful conduct, investors cannot be considered to have violated international law. ${ }^{32}$ Such arguments yet again demonstrate a structural imbalance at the very core of international investment law. The investor is seen as deserving and indeed needing international legal standing so as to benefit from extensive treaty privileges and protections vis-à-vis host states, but when the issue of responsibilities comes to the fore investors are seen as (conveniently) lacking an international legal personality. ${ }^{33}$

Some also argue that it is the host states, not investors, that bear ultimate responsibility for ensuring that investment projects are sustainable and designed so as to minimize negative environmental and social impacts. ${ }^{34}$ Those who oppose the inclusion of express investor obligations in treaty texts ignore the fact that negative impacts of foreign investment tend to foment both the dissatisfaction with the regime at a global and national level and the resentment against concrete investment projects on the ground. The failure to incorporate investor responsibilities in treaty texts might in the long-term prompt discontent and resistance among local communities and thus destabilize and undermine the commercial success of investment projects. There is a growing recognition among some in the business community that a successful investment project necessitates not only a political license but also a social license, including through direct engagement with local communities. ${ }^{35}$ Since certain investor obligations were common in contractual practice before the rise of IIAs, their revival in investment treaty practice would not be entirely unprecedented. ${ }^{36}$

\footnotetext{
29 See also Investment Agreement for the COMESA Common Investment Area, May 5, 2007 which to a certain extent seeks to address investment conduct.

${ }^{30}$ Sergio Puig \& Gregory Shaffer, Imperfect Alternatives: Institutional Choice and the Reform of Investment Law, 112 AJIL 361, 367 (2018).

${ }^{31}$ Nowrot, supra note 23, at 631.

32 Id.

${ }^{33}$ Under traditional international law it is still questionable whether corporations can be held reponsible for international law violations. See, e.g., Ian Brownlie, Principles Of Public International Law 65 (2003). This is reflected in Ruggie's Guiding Principles, see Guiding Principles on Business and Human Rights: Implementing the United Nations 'Protect, Respect and Remedy' Framework, UN Doc. HR/ PUB/11/04 (2011).

${ }^{34}$ For an overview, see Peter Muchlinski, Multinational Enterprises and the Law 515 (2007).

35 Asel Doolot \& John Heathershaw, State as Resource, Mediator and Performer: Understanding the Local and Global Politics of Gold Mining in Kyrgyzstan, 34 Central Asian Surv. 93, 104 (2015).

36 See, e.g., Zhiguo Gao, International Petroleum Contracts: Current Trends and New Directions (1994).
} 
Perhaps international lending institutions and other international advisory bodies could step in and advocate for the inclusion of investor obligations in new IIA templates. After all, such institutions have played an important part in the original diffusion of IIAs and ISDS in 1980s. Reframing investment treaty goals ${ }^{37}$ is also crucial to overcome the current resistance to embrace new drafting approaches. Tweaking IIAs to incorporate declaratory references to corporate social responsibility only distracts from the need to revisit the bigger issue of the regime's key goals. As the distributive implications of corporate activities are increasingly raising concerns for stakeholders in both developed and developing states, a radical overhaul of investment treaty objectives is warranted in order to address the existing asymmetry of responsibilities they impose on states and investors.

37 Shaffer \& Puig, supra note 30 , at 368. 